\title{
Knowledge and Humility of Hazrat Abu Dharr Ghafari (An Analytical Study)
}

* Dr. Hafiz Muhammad Ibrar Ullah, Assistant Professor (Corresponding Author)

** Dr. Hashmat Begum, Assistant Professor

*** Dr. Samina Begum, Assistant Professor

\begin{abstract}
Hazrat Abu Dharr Ghaffari (RA) is a glorious Companion, and in fact, the Companions are the people whom Allah has chosen to accompany His Messenger (SAW). He took up permanent residence in a village in Syria and then moved to Damascus during the caliphate of Hazrat Usman Ghani (RA) and continued his sermons- He spent the last days of his life in the suburbs of Madinah. The tribe belonged to the Bani Ghiffar. After accepting Islam, they fell in love with the Holy Prophet, He did not like to accumulate wealth in the world. He used to avoid meeting people unnecessarily - He was not afraid of anyone when he spoke the truth, while he endured all kinds of hardships for the sake of Islam. You used to say that people are born to die. The Prophet (peace and blessings of Allaah be upon him) gave him the title of "Masih al-Islam". After him, he became detached from the world. Hazrat Umar (RA) considered him equal to Abdullah bin Masood in knowledge.

Keywords: Humility, Hardships, Blessings

\section{Introduction}

Hazrat Abu Dharr Ghaffari's name is "Jundab" and his father's name is "Junadat". Some have mentioned Sakan, Sufyan, and Abd. He was a tall, wheat-colored man with a beautiful body (Al Barr, 1993). Hazrat Abu Dharr (RA) became a Muslim at number four. He says: A total of three people became Muslims before me, and I became a Muslim at number four (Al-Isphahani, 1996). Hazrat Abu Dharr Ghaffari (RA) is one of the prominent students of Safa. His statement is: I was among the companions of Safa. When it was evening, we would go to the Holy Gate of the Prophet (peace be upon him) (Muhammad, 1997). He belonged to a very brave Arab family in his time. It is said that no caravan passing by the family escaped unharmed. Before the Acceptance of Islam, Hazrat Abu Dharr Ghaffari was a monotheist and hated idolatry. He says that he used to worship Allah according to his taste, sometimes he would bow down, sometimes he would prostrate (Al Rashidi, 2008).
\end{abstract}

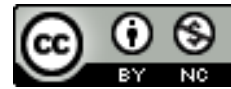

\section{Hazrat Abu Dharr Ghaffari's conversion to Islam}

Hazrat Abu Zarghafari (RA) narrates that we left our nation "Ghaffar" because these people considered haraam months as halal. My brother Unis and my mother all three said goodbye to their Ghaffar tribe together, and came and stayed with their uncles. They treated us very kindly and they treated us with great kindness, which made their people We became jealous of the people and said to our uncles, "Sir, when you go out and there is no one left in the house. Your nephews are officers over peopleHearing this, our uncles came and started questioning. I heard so much that I said to my uncles! You have tainted the canals of all past favors, but after that, our gathering with you is not possible. Eventually, we went to our camels and left with our belongings. The uncles used to cover their faces with cloth and cry. We kept walking and reached near Makkah. One day Unais said! I have a job in Makkah, you stay here, I will go, he went and he delayed his return, on his return I inquired, what did you do to me? He said, "I met a man in Makkah who is a follower of your religion, ie, a monotheist, and he worships Allah and he says that Allah has sent him." I discovered, what do people call it? He said, "People may call him a priest and a magician, and Unais was a poet himself." He said, "I have heard the word of the priests, but the word that this man reads is not the word of the priests, and I have examined his word on all the seas and weights. Poems are not, I swear by God, it is true and they are all liars. I said, 'Stay here. I will come to see this person myself.' Then I came to Mecca and looked for the weak in Makkah, (Because I was more likely to get hurt if I asked a strong person and there was no danger from a weak person) And asked him, "Where is the man whom you call Sabi?

\footnotetext{
* The University of Azad Jammu \& Kashmir Muzaffarabad Email: hafizibrar87@gmail.com

** Shaheed Benazir Bhutto Women University Peshawar Email: hashmat.begum@sbbwu.edu.pk

*** Shaheed Benazir Bhutto Women University Peshawar Email: saminaphd@ hotmail.com
} 
The disbelievers of Arab used to call the Prophet Muhammad (peace be upon him) Sabi. He pointed at me and provoked the people and said that this is a Sabi man -Upon hearing this, the people of Makkah loosened their bones and fell on me and fell in a daze. When I woke up, I saw myself as a red idol (bathed in the blood). The time came for Zamzam, I drank water and washed my blood, I stayed there for thirty days, I had no food other than Zamzam water, I used to drink it when I was hungry, Until (due to obesity) the buttocks of my stomach hung, and I did not feel the energy of hunger in my brain at all (AL-Naysābūrī. 2004). In those days, Hazrat Ali (RA) passed by the Kaaba at night. He saw that there was a foreign traveler. He came to his house and hosted him. Are you The traveler also did not show anything. In the morning he came back to the Masjid al-Haram. He kept his basket and musk in the streets and bazaars of Makkah until evening, but he did not succeed. He passed by the Haram, saw them, and said: Is it not time for a man to go to his Place? Saying this, he took them with him and came home. he came to Haram Sharif early in the morning. (Al Bukhari, 2006 ). Tonight a strange event took place which he narrates: The moonlit night was very bright, the people of Makkah were busy with their work when suddenly the mighty power of Allah Almighty slapped them. There was no one else. Only two women, "Assaf" and "Naila", came to me while performing Tawaf. I said, "Marry one of them to the other." This time I said clearly: wood in their so-and-so. Let these women hear and blaspheme openly about their God and say, I wish! If any man of my group was here at that time, he would have taken notice of it-On the way, the women met the Prophet (peace and blessings of Allaah be upon him) and Hazrat Abu Bakr al-Siddique (RA) coming from the mountainside. The Prophet (peace and blessings of Allaah be upon him) asked them: What happened? They speak! A Sabi is hidden in the curtains of Kaaba Sharif, he Asked again! What did he say? They speak! It is not a matter of bringing up the tongue. He is saying a very bad thing. After this conversation, she left. And the Prophet (peace and blessings of Allaah be upon him) came to the Kaaba with his companion, kissed the Hijr e Aswad and performed Tawaaf and then offered the prayer. When he finished praying, Abu Dharr said: I was the first to perform the Sunnah of Islam. I said, "Assalam O Alaika Ya Rasool Allah. The Prophet (peace and blessings of Allaah be upon him) said:wa Alaika Salam Warhmtullah. Then the Prophet (peace and blessings of Allaah be upon him) asked: Who are you? I said, "I am a member of the Ghaffar tribe." Upon hearing this, the Prophet (peace and blessings of Allaah be upon him) lowered his hand towards his forehead and nodded. I said in my heart that perhaps you disliked my attribution to Ghaffari. (AL-Naysābūrī. 2004)

The reason for the beheading of the Prophet (peace and blessings of Allaah be upon him) is stated in a narration of "Tabqaat Ibn Saad" that The Holy Prophet (peace and blessings of Allaah be upon him) wondered why the tribe of Ghaffar used to rob (How such a person was born among them). The Messenger of Allaah (peace and blessings of Allaah be upon him) looked at them in amazement, because the Ghaffar was well aware of the situation. Then he said: Surely Allaah guides whom He wills. (Muhammad, 1997) Hazrat Abu Dharr says: I tried to grab your blessed hand, but his companion (Hazrat Abu Bakr Siddiq) stopped me. He was more aware of the nature of my Prophet (peace be upon him) than he was. Then he said, "How long have you been here?" I replied: Thirty nights have passed here, He said: Who feeds you? I said: There is no food except Zamzam water, etc., but I live on Zamzam water, I became fat, until (due to obesity) my stomach cramps hung, and I felt the weakness of hunger in my heart. Upon hearing this, the Prophet (peace and blessings of Allaah be upon him) said: The water of Zamzam is blessed, and it is a source of food and drink (AL-Naysābūrī. 2004). He asked the Prophet (peace and blessings of Allaah be upon him) to recite some verses of the Quran. He recited a surah of the Holy Quran, Upon hearing this, Hazrat Abu Dharr recited the " Kalmah Shahadah" aloud and at the same time became a Muslim. Shortly afterward, Abu Bakr came and the Prophet (peace and blessings of Allaah be upon him) gave him the good news of Islam. Hazrat Abu Bakr recognized him by looking at him carefully and said: Isn't he the person who was my guest? He replied: Why not!! Then Hazrat Abu Bakr said: "Antalaq Mai" Come with me, Hazrat Siddiq Akbar (RA) took him to his house and took out his long and beautiful clothes, changed his clothes, and As long as he stayed in Makkah, he stayed at the house of Hazrat Abu Bakr. (Muhammad, , 1997) . Hazrat Abu Dharr was a monotheist before he converted to Islam even before the conversion to Islam, Hazrat Abu Dharr was a believer in the Oneness of God and did not worship idols (ALNaysābūrī. 2004). Once he addressed his nephew and said, "O my nephew! I used to offer prayers three years before the blessed visit of the Prophet (peace and blessings of Allaah be upon him)."The narrator, seeing the polytheism and disgrace of the Arabs, heard the name of the prayer and asked 
with great surprise. Who did you pray for? He said: "For the sake of Allah!" He discovered! Which way did they turn? He replied: To which my Lord would turn. I used to offer Isha prayers and when it was late at night, I would fall like a blanket until the sun would start shining on me (Al Bukhari, 2006).

\section{Devotion and love for the Holy Prophet}

When Hazrat Abu Dharr came to Madinah, He fell in love with the Holy Prophet (peace and blessings of Allaah be upon him) so firmly that he never thought of parting. The Prophet (peace and blessings of Allaah be upon him) also loved with him. If he had come to the meeting, he would have first inquired about the well-being of Hazrat Abu Dharr (Al-Dhahabi, 1994) The Prophet (peace and blessings of Allaah be upon him) came to Madinah and fought battles like Badr and Uhud, then Abu Dharr came (Muhammad, 1997). And half of the people of the Ghaffar tribe who did not become Muslims also came and became Muslims and the people of the tribe of Aslam came and said, $\mathrm{O}$ Messenger of Allah! We are Muslims like our Ghaffari brothers. Seeing this scene, the Prophet (peace and blessings of Allaah be upon him) said: May Allaah forgive Ghaffar and may Allaah keep Aslam safe (AL-Naysābūī. 2004) The Prophet (peace and blessings of Allaah be upon him) said: Allaah has commanded me to love four people and Allaah Himself loves them. The Companions asked, "O Messenger of Allah, tell me the names of these fortunate ones." First, he took the name of Hazrat Ali and three times his name. Then mention the names of Abu Dharr, Muqdad, and Salman. After mentioning these names, the Prophet (peace and blessings of Allaah be upon him) said, "Allaah has commanded me to love these four people and told me about myself that I love them too." (Tirmidhī,. 1999).

\section{Hazrat Abu Zar Ghaffari's Knowle dge}

Hazrat Abu Dharr (RA) gained a lot of knowledge by living with the companions of Safa and by becoming a servant of the Prophet (PBUH) and the Prophet (PBUH) himself addressed them and taught them the knowledge of asceticism and piety.

Hazrat Abu Dharr (RA) was a distinguished student of the Companions of Safa as well as a distinguished servant of the Holy Prophet (PBUH). The Holy Prophet (sws) was very happy with his service. Similarly, Hazrat Abu Dharr (RA) was prominent among all the Companions in asking scholarly questions to the Prophet (peace and blessings of Allah be upon him). Hazrat Ali (RA) says about him that they used to ask the Prophet (peace and blessings of Allaah be upon him) a lot of questions ، Sometimes he would get an answer ' And sometimes the answer is no (Muhammad, 1997). Seeing their intellectual passion and enthusiasm, the Prophet (peace and blessings of Allaah be upon him) repeatedly addressed them and irrigated them with the source of Prophethood, and especially gave them a lot of advice. And there are some hadiths which have been narrated by the Prophet (peace and blessings of Allaah be upon him), especially in solitude. Assuming that they learned a lot from the Prophet (peace and blessings of Allaah be upon him)He says that the Prophet (peace and blessings of Allaah be upon him) left us when we got some knowledge about the birds flying in the air. (Ahmad, 1999) The Ali (RA) while highlighting the scholarly position of Hazrat Abu Dharr said, "Hazrat Abu Dharr has acquired such knowledge from which people have become helpless. The fact that they were so greedy and greedy, in what? He says: He was greedy to follow the religion and follow its words and was eager to acquire know ledge. He used to ask the Prophet (peace and blessings of Allaah be upon him) a lot, but he was never answered. For this myth, their scale of knowledge was so full that it became full. Hazrat Ali once said: Abu Dharr is the mountain of knowledge, he has stored all the knowledge in his chest (Muhammad, 1997).

\section{Teaching circle}

Hazrat Abu Dharr's formal teaching council was not established in any particular place, but wherever and whenever people discovered the hadith of the Prophet (peace be upon him), his teaching circle was established. Once a man came and said: O Hazrat Abu Dharr! I would like to ask you about the Prophet (peace and blessings of Allaah be upon him) On hearing this, he replied, "I will not tell you the mysteries and secrets that the Prophet (peace and blessings of Allaah be upon him) has told you. If you ask me, I will tell you anything else." .( Al-Isphahani, 1996 ) Allama Shams-ud-Din Dhahabi states: Hazrat Abu Dharr(RA), Hazrat Abu Bakr(RA), Hazrat Umar(RA) and Hazrat Uthman(RA) used to give fatwas during the time of Khilafat (Al-Isphahani, 1996). 


\section{Hazrat Abu Dharr's me thod of preaching}

Whenever the sound of a decade of the name of other than Allah resounded in the ears of Hazrat Abu Dharr, his zeal for faith would be aroused. Seeing their brave character and zeal for the faith and showing compassion to them, the Prophet (peace and blessings of Allaah be upon him) wanted to send them as the first preacher of his people, but also of Islam. I have been shown the land of palms and I do not think of any city other than Yathrib (Madinah Munawwara). Can you preach to my people and invite people to religion on my behalf? May Allah Almighty benefit them from your caste and reward you for preaching among them (Muhammad, 1997). He returned home by the order of the Prophet (peace and blessings of Allaah be upon him) and first met his brother Hazrat Unais. He was waiting. He said: I became a Muslim and confirmed the prophethood of Muhammad (peace and blessings of Allaah be upon him). Upon hearing this, he said: I have no hatred or denial of your religion. I too became a Muslim and confirmed the prophethood of Muhammad (peace and blessings of Allaah be upon him). Continuing the preaching campaign, they both came to their mother. Seeing this situation, she said, "I do not hate the religion of both of you. I also became a Muslim and I also sent the message of Muhammad (peace be upon him)." Confirmed. (AL-Naysābūrī. 2004)

\section{Satisfaction of Hazrat Abu Dharr}

Hazrat Abu Dharr narrates that once I was walking with the Holy Prophet (sws) in the black rocky land of Madinah. The Prophet (peace and blessings of Allaah be upon him) said: O Abu Dharr! He said: O Messenger of Allah! Then he said: O Abu Dharr! If I have gold equal to this mountain of Uhud, I would not like it at all if an Ashrafi equivalent of gold remains with me till the third day. Is. I will divide the gold among the servants of Allah, right and left, and back (on all three sides) among the needy. Listen! Those who have a lot of wealth in this world and are called capitalists will be the ones who will be poor in the hereafter except the one to whom Allah has given wealth, then let him lie down on his right hand, on his left, and on his back, that is, give to the needy and the poor .( AlIsphahani, 1996 ) Muhammad(peace and blessings of Allah be upon him) once said that "the sky did not spread its canopy on any man who was more truthful than Abu Dharr. (Razwy, 1998). Hazrat Abu Dharr (RA) was a great personality as well as a person who thought about the Hereafter and was always engaged in the remembrance of Allah Almighty.(Faridi 1996) One of the special teachings of Islam is to be gentle and easy in dealing and in all kinds of behavior.. Islam has declared good speech as good and harsh speech as sin. And all these attributes were present in Hazrat Abu Dharr Ghaffari, he liked simple temperament and simplicity (shahdi, 2000).

\section{Fune ral of Hazrat Abu Dharr}

Hazrat Abu Dharr, may Allah bless him and grant him peace, made Rabza, a small settlement, his homeland, and spent the last days of his life in that land.

When the time came for the death of Hazrat Abu Dharr (RA), his wife Mohtarma's eyes became teary and she started weeping profusely. Hazrat Abu Dharr asked, "Why did you cry?" He replied: The appointed time has come for you and I am a woman, I do not have the strength to dig a grave for you in this rocky earth and there is not even a small cloth in the house in which I can give you a shroud. Abu Dharr began to say! Don't cry One day I was with the Prophet (peace and blessings of Allaah be upon him) in the company of the Companions. At that time he (peace and blessings of Allaah be upon him) said: One of you will die in the desert of Sansan. One party will participate. I have been guessing since that day that all the people there have died in a city or a village and now I am the only one who is dying in this desolate valley. When they saw a woman alone in the Sansan valley, they stopped their rides near her and in unison they discovered! Why are you standing here What happened to you? She replied! Muslims! It is the last time for a Muslim person to make a shroud for him, you will get a beautiful reward in the presence of God Almighty. The caravan asked! Who is that Muslim person? The sound came! Abu Dharr Companions of the Prophet (peace and blessings of Allaah be upon him)! Hearing this, they lost consciousness. The listeners made a noise. May our parents be sacrificed on them. May our parents be sacrificed on them. These noises came down from the camels, whipped them, hung whips around their necks, and rushed forward and reached Hazrat Abu Dharr. ( Al Hazrami, 2004) Assuming that these gentlemen gave the shroud and as per his will his body was taken away and placed on the common passage, From Kufa, the teacher of Kufa, the jurist of the ummah, Hazrat Abdullah bin Masood (may Allah be pleased with him) was in ihram for HajjA slave stepped forward and said! This is Abu Dharr - Help us with his funeral. According to the narration of Ibn Ishaq, on hearing this sentence, Hazrat Abdullah ibn Mas'ud shouted 
and started weeping loudly, weeping and saying this. The Prophet (peace and blessings of Allaah be upon him) said the truth: May Allaah have mercy on Abu Dharr! It runs alone, will die alone, and will be raised alone. Then he went ahead and led the funeral procession and all these gentlemen buried him in the land of Rabzah in $31 \mathrm{AH}$ or $32 \mathrm{AH}$ (Al Tabari, 1997).

\section{Conclusion}

Hazrat Abu Dharr Ghaffari is the Companion who was addressed by the Holy Prophet in various hadiths: O Abu Dharr, O Abu Dharr! Numerous hadiths have been narrated from you. He was very content and simple. Combining various narrations shows that these people were Yemenis and were coming from Kufa, along with the famous Companion Abdullah ibn Mas'ud, who was going to Iraq. However, this Ansari young man shrouded them and Abdullah ibn Mas'ud Funeral prayers, Your diet consisted mostly of goat's milk, but you also shared it with guests and neighbors. Hazrat Abu Dharr's condition was such that he did not want to see where he was lying until he lay down. Nor were you tired of weak clothes and You didn't care about its beauty and splendor. According to the statement of Allama Shams-ud-Din Dhahabi, the total number of hadiths of Hazrat Abu Dharr is 281.

\section{References}

Al Barr, Y,I,A, (1993). Al-Isti'ab fi ma'rifat al-ashab ( vol.04 ).Dar Ahya ut tura , beriut

Al-Isphahani, A,N,A , (1996). Hilyat ul- Awliya wa Tabaqat-ul-Asfiya, (vol.05), dar ul kutub ilmia, labnon.

Al Rashidi ,M,Z, (2008),seerat nabavi , maktabh nizampur , india

AL-Naysābūrī. (2004) . Muslim bin Al hujjaj , Sahi Muslim , (vol.01), labnan.

AL-Naysābūrī. (2004) . Muslim bin Al hujjaj, Sahi Muslim , (vol.02), labnan.

Al Bukhari ,M,B,I (2006 ). Sahi al Albukhari , (vol.01), Mu'assasat al-Risalah,bayrut

Al-Dhahabi ‘S,M,I (1994).Siyar a lam al-nubala' (vol.02 )Mu'assasat al-Risalah,bayrut

Ahmad , B, H,( 1999). Musnad Imam Ahmad Bin Hanmbal , (vol,04 ). Dar Ul taqwah, beruit

Al Hazrami , A,B,M, (2004). Tarikh Ibn Khaldun, (VOL.07) New York: Princeton.

Al Tabari, M, B, J, (1997), Tareekh Al Tabari, (vol.08) Cambridge University Press

Faridi ,I,I,(1996). The life of Abu Dharr, Kessinger Publishing

Muhammad ,B,S, (1997). Tabqaat Ibnne Saad,(vol.01) Inab press, labnan

Razwy, S, A, A,(1998). A Restatement of the History of Islam \& Muslims. Islamic Seminary Publications

Shahidi , S,T,(2000), World's Religions, (vol.13). saeedi Research and Publishing

Tirmidhī, M. I. (1999) Jami' al-Tirmidhi. Karkhana Tijarat Kutab. Karachi 